\title{
ANALYSIS OF UNDERSTANDING OF STUDENT CONCEPTS IN SOLVING ABSOLUTE VALUE PROBLEMS
}

\author{
*Patma Sopamena ${ }^{1}$, Ryan Andriansyah ${ }^{2}$, Kalsum Sopamena ${ }^{3}$ \\ ${ }^{1}$ Program studi Pendidikan Matematika, Institut Agama Islam Negeri Ambon, Indonesia \\ ${ }^{2}$ Program studi Pendidikan Matematika, Institut Agama Islam Negeri Ambon, Indonesia \\ ${ }^{3}$ Guru SD N 5 Tawiri Ambon, Indonesia \\ ${ }^{1}$ Patma.sopamena@iainambon.ac.id
}

\begin{abstract}
Abstrak
Tujuan penelitian ini adalah untuk mendeskripsikan pemahaman konsep dalam menyelesaikan masalah nilai mutlak. Penelitian ini merupakan penelitian deskriptif kualitatif. Dalam penelitian ini peneliti sebagai instrumen utama dan tes uraian menjadi instrumen pendukung. Data penelitian diperoleh dari hasil think alouds dan wawancara. Penelitian ini dilaksanakan di SMA Negeri 11 Ambon dengan subjek penelitian dalam tulisan ini sebanyak 1 orang yang diambil berdasarkan snowballsampling dari 9 siswa. Hasil penelitian menunjukkan bahwa pemahaman konsep siswa diawali dengan menerjemahkan bentuk abstrak ke bentuk yang lebih kongkrit, yakni dengan menentukan hal yang diketahui dan hal yang ditanyakan.Selanjutnya menginterpretasikan penyelesaian masalah secara algoritmik, dan langsung dapat menarik kesimpulan atau mengekstrapolasi.
\end{abstract}

Kata kunci: Nilai Mutlak, Pemahaman Konsep, Penyelesaian Masalah

\begin{abstract}
The purpose of this study is to describe the understanding of concepts in solving absolute value problems. This research is a qualitative descriptive study. In this study, researchers as the main instrument and essay tests become supporting instruments. The research data were obtained from think aloud and interviews. This research was conducted in Ambon 11 Public High School with the research subjects in this paper as many as 1 person taken based on snowball sampling from 9 students. The results showed that understanding students' concepts begin with translating abstract forms into more concrete forms, namely by determining what is known and what is asked. Furthermore, interpreting problem solving algorithmically or completely and can immediately conclude or extrapolate.
\end{abstract}

Keywords: Absolute Value, Understanding Concepts, Problem Solving

Citation: Sopamena, P., Andriansyah, R., Sopamena, K. 2019. Analysis of Understanding of Student Concepts in Solving Absolute Value Problems. Matematika dan Pembelajaran, 7(2), 42-50. DOI: http://dx.doi.org/10.33477/mp.v6i2 


\section{INTRODUCTION}

Understanding of mathematical concepts is an ability that must be possessed by students in solving problems. However, based on the 2015 annual TIMSS Survey, Indonesia ranked 45th out of 51 (Reddy et al., 2016: 21). Meanwhile, PISA's three (3) annual studies, in 2015 placed Indonesia in 62th out of 70 countries (OECD, 2013). Therefore understanding the concept needs to be examined in studies of mathematics education. According to Sanjaya, concept understanding is the ability of students in the form of mastery of a number of subject matter, where students not only know or remember a number of concepts learned but are able to express it again in other forms that are easy to understand, provide interpretation of data and are able to apply concepts in accordance with the structure cognitive (Sanjaya, 2010). Understanding concepts is one of the most important goals in learning mathematics. The importance of understanding mathematical concepts is seen in the first goal of learning mathematics, namely understanding mathematical concepts, explaining the relationship between concepts and applying concepts or algorithms flexibly, accurately, efficiently and precisely in problem-solving. In accordance with the objectives of learning mathematics above, then after the learning process students are expected to understand mathematical concepts so that they can use these abilities in dealing with mathematical problems (Depdiknas, 2008). So it can be said that understanding concepts is the most important part of learning mathematics.

Furthermore, the problem of understanding mathematical concepts is closely related to how the nature of mathematical knowledge is understood (Godino, 1996). Mathematical terms and expressions indicate abstract entities whose nature and origin must be examined to describe theories that are useful and effective for understanding mathematical objects. Mathematical knowledge is information that is represented internally, understanding occurs when the representation achieved is connected by an increasingly structured and cohesive network (Carpenter \& Lehrer, 1999). In the results of the project research, Carpenter explained that out of the four research projects, a consensus emerged about what it meant to understand mathematics and what was important to facilitate 
student understanding. The principles agreed upon include: First, understanding can be characterized by the type of relationship or connection that has been established between ideas, facts, procedures, and so on. Second, there are two cognitive processes that are key in students' efforts to understand mathematics-reflection and communication (Hiebert et al., 2000). So understanding mathematical concepts is an internal ability possessed by mathematicians in making the connection between the nature of basic mathematical knowledge through reflection and communication.

Bloom divides understanding into three types, namely; understanding translation, understanding interpolation, and understanding extrapolation (B. S. Bloom \& Krathwohl, 1956: 204-205); (B. Bloom, 1957). The first is a translation which means that one can put communication into another language, into another term, or into another form of communication (B. S. Bloom \& Krathwohl, 1956: 204). Usually, it will involve giving meaning to various parts of communication, taken separately, although the meaning can be partly determined by the context in which the idea arises. The second type of behavior is an interpretation that involves dealing with communication as a configuration of ideas whose understanding may require the rearrangement of ideas into new configurations in the individual's mind (B. S. Bloom \& Krathwohl, 1956: 205). This also includes thinking about the relative importance of ideas, their relevance, and their relevance to generalizations that are implied or explained in the original communication. Evidence of interpretive behavior can be found in conclusions, generalizations, or summaries produced by individuals. The third type of behavior that must be considered under understanding is extrapolation. This includes making estimates or predictions based on understanding trends, trends, or conditions described in communication (B. S. Bloom \& Krathwohl, 1956: 205). This may also involve making conclusions with respect to the implications, consequences, corollary and effects that are in accordance with the conditions described in the communication.

Understanding of mathematical concepts has also been studied by (Crooks \& Alibali, 2014); (Ghazali \& Zakaria, 2011); (De Zeeuw, Craig, \& You, 2013); (Zahner, Velazquez, Moschkovich, Vahey, \& Lara-Meloy, 2012); (Mills, 2016); (Tatar \& Zengin, 2016). Ghazali \& Zakaria said that the level of students' 
procedural understanding was high while the level of conceptual understanding was low. They have higher procedural understanding gains compared to conceptual understanding gain. De Zeeuw, Craig, \& You explained that the assessment using Netlogo would be very useful for mathematics educators to have a good tool for assessing students' conceptual understanding, as well as for developing teaching strategies used. Research result Mills, that important dimensions of conceptual understanding are identified as factual and procedural knowledge, connections, transfers, and metacognition. The results reinforce conceptual understanding as a process.

Based on these studies, understanding the concept of mathematics as an individual's internal process in processing information obtained in problem-solving has not been studied. This is the focus of this research. Furthermore, understanding the mathematical concepts in this study were analyzed using three understandings in Bloom's taxonomy, namely understanding translation, understanding interpretation, and extrapolation understanding.

\section{METHOD}

This research approach is a qualitative descriptive that aims to describe the understanding of student concepts in solving boundary problems based on Bloom's taxonomy. The subjects in this study were grade X students in Ambon 11 Public High School which consisted of 2 classes totaling 78 students. From 9 students each student was taken as a research subject and then given essay test questions and asked to be completed with think aloud (Creswell, 2012: 225-245). In setting research subjects using snowball sampling techniques (Creswell, 2012: 45). Snowball sampling is a data source sampling technique which at first the amount was not able to provide complete data, then had to find other people who could be used as data sources. The process of taking the subject is based on the concept of understanding the criteria (Creswell, 2012).

The researcher is the main instrument in this study and is assisted with supporting instruments, namely the description test and interview guidelines 
(Creswell, 2015), whose transcript results become research data. Next, the research data were analyzed by adopting several steps: (1) making verbal data transcripts from think aloud and interviews, (2) examine all the data that has been transcribed, namely data from the results of think aloud, interviews, observations that have been written in field notes, and the results of students' mathematical concept construction, (3) conduct data reduction on understanding the concept of a limit based on Bloom's taxonomy, which is an attempt to make a summary of the core, process, and statements that need to be maintained in order to remain consistent, (4) arrange in units which are further categorized by making coding, (5) analysis of the process of understanding the concept of subject limits based on Bloom's taxonomy, (6) analysis of interesting things, and (7) drawing conclusions (Sopamena, 2017).

\section{RESULTS AND DISCUSSION}

\section{Understanding of the concept of S1 in the Problem Solving Absolute Value}

$\mathrm{S} 1$ is a representative of the subject who answers correctly or does not make mistakes in solving absolute value problems. When S1 solves the problem of absolute value, understanding the concept of S1 is completed, marked by when S1 resolves the problem without finding errors before reflection (the answer is correct and meets the characteristics of understanding the concept). The problem under study is " Cars with brand A, write the number of gasoline consumption, which is $12 \mathrm{~km} / \mathrm{L}$. The index of the range of car A is 5. If Arman drives a car with 1 liter remaining, then what is the distance Arman has to at least fill up with gasoline and what is the maximum distance Arman can drive?"

Furthermore, S1 begins the solution by understanding the translation process, that $\mathrm{S} 1$ understands the known problem so that it can translate abstract material into a more concrete form mathematically, that is, S1 writes the things that are known and asked of the question of absolute value. like the S1 statement as follows.

S1: So what is meant by No. 2, for example, s is the distance traveled, and the consumption of gasoline used is $12 \mathrm{~km} / \mathrm{L}$, and the index for the range of car 
$A$ is less than 5, then there are two questions, namely; at what distance does Arman have to fill gasoline and what is the maximum mileage that Arman needs? so we can write the absolute value equation is $|s-12| \leq 5$

In writing things that are known, S1 directly writes the initialism (s) is the mileage, the consumption of gasoline usage is $12 \mathrm{~km} / \mathrm{L}$, and the car range index is less than 5 , so $\mathrm{S} 1$ gets an absolute value, namely $|s-12| \leq 5$. Such a step can show that $\mathrm{S} 1$ has an understanding of the concept of understanding translation. This is in line with what was conveyed by Bloom that As explores the work of S1 in Figure 1 below.

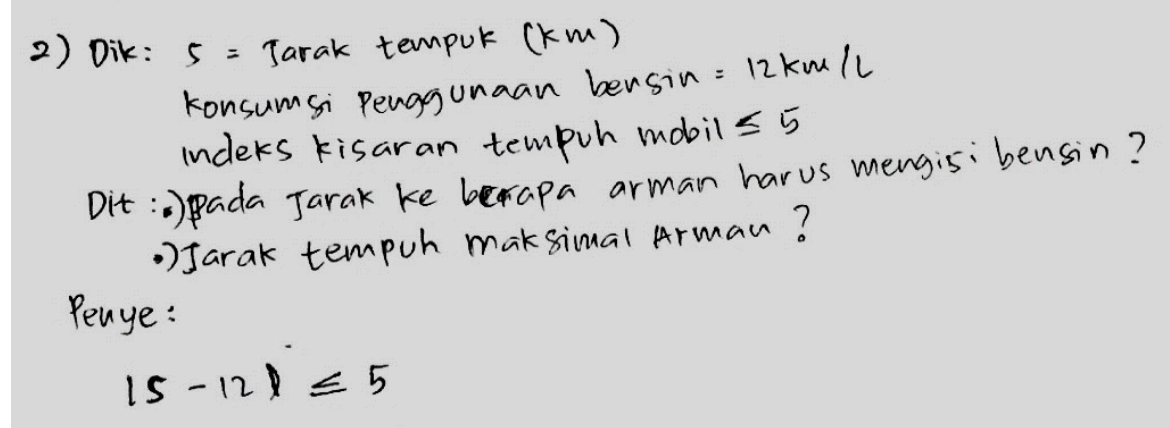

\section{Figure 1: S Work Results in Translating Problems}

Next, S1 begins to understand the whole framework of completion. From this step, $\mathrm{S} 1$ writes the form of the absolute value equation and completes it step by step. thus $\mathrm{S} 1$ makes understanding interpretation. As in Figure 2 below.

$$
\begin{gathered}
-5 \leqslant 5-12 \leq 5 \\
-5+12 \leq 5-12+12 \leqslant 5+12 \\
7 \leq 5 \leq 17
\end{gathered}
$$

Figure 2: S1 Job Results in Interpreting Problems

This is confirmed by the $\mathrm{S} 1$ statement when interviewed as follows.

$P$ : How can you get the inequality results from the absolute value

S1: because here using the sign is less than equal to so $-5 \leq s-12 \leq 5$, then each section we add to the number 12 so we get, $-5+12 \leq s-12+12 \leq 5+12$ then we operate $7 \leq s \leq 17$ 
Next, S1 makes a conclusion. This makes S1 understand extrapolation, which is to make generalizations or summaries resulting from problem-solving (B. S. Bloom \& Krathwohl, 1956); (B. Bloom, 1957). as in Figure 3 below.

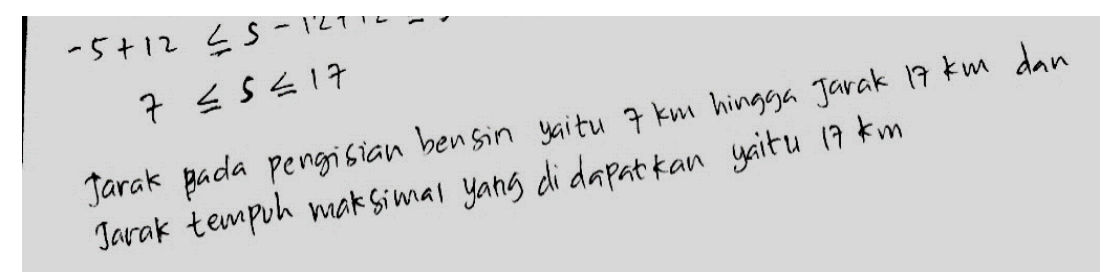

Figure 3: S Work Results in Making Conclusions

Next, S1 is asked to reflect on his work. After S1 makes a reflection, S1 remains confident in its work. This is confirmed by the results of interviews with researchers as follows:

\section{$P:$ Are you sure about that answer? \\ S1: I believe \\ $P$ : "Don't want to check again?" \\ S1: "( check again), I am sure"}

So it appears that $\mathrm{S} 1$ in solving this absolute value problem, S1 applies the criterion of understanding the Bloom concept, namely; understanding translation, understanding interpretation, and understanding extrapolation. This is in line with what is described by Bloom as known as the stage of Bloom's cognitive taxonomy (B. Bloom, 1957); (B. S. Bloom \& Krathwohl, 1956).

\section{CONCLUSION}

Based on the results of research and discussion, it can be concluded that the students of Ambon 11 Public High Schools, especially S1 in solving the problem of absolute values, do understanding concepts. The understanding of concepts by students, among others, begins by translating abstract forms into more concrete forms. Characterized by students can directly determine what is known and what is asked, then students interpret by understanding the framework of an overall work (Algorithm), and can immediately draw conclusions or extrapolate. This research is still limited to the stages of understanding of Bloom's taxonomy, so it is still possible to examine how the other stages of Bloom's taxonomy occur. 


\section{REFERENCES}

Bloom, B. (1957). Learning domains of Bloom's taxonomy. Retrieved November.

Bloom, B. S., \& Krathwohl, D. R. (1956). Taxonomy of Educational Objectives: The Classification of Educational Goals. In Handbook I: Cognitive Domain.

Carpenter, T. P., \& Lehrer, R. (1999). Teaching and learning mathematics with understanding. In Mathematics Classrooms that Promote Understanding.

Creswell, J. W. (2012). Educational research: Planning, conducting, and evaluating quantitative and qualitative research. In Educational Research. https://doi.org/10.1017/CBO9781107415324.004

Creswell, J. W. (2015). Penelitian Kualitatif dan Desain Riset (memilih diantara lima pendekatan). In Penelitian Kualitatif.

Crooks, N. M., \& Alibali, M. W. (2014). Defining and measuring conceptual knowledge in mathematics. Developmental Review. https://doi.org/10.1016/j.dr.2014.10.001

De Zeeuw, A., Craig, T., \& You, H. S. (2013). Assessing conceptual understanding in mathematics. Proceedings - Frontiers in Education Conference, FIE. https://doi.org/10.1109/FIE.2013.6685135

Depdiknas. Permendiknas No 22 Tahun 2006. Tentang Standar Isi Pendidikan Dasar dan Menengah., Jakarta § (2008).

Ghazali, N. H. C., \& Zakaria, E. (2011). Students' procedural and conceptual understanding of mathematics. Australian Journal of Basic and Applied Sciences.

Godino, J. D. (1996). Mathematical Concepts, Their Meanings, and Understanding. Psychology of Mathematics Education-PME2O.

Hiebert, J., Carpenter, T. P., Fuson, K. C., Wearne, D., Murray, H., Olivier, A., \& Human, P. (2000). Making Sense. Chapter 1. In Making sense: Teaching and learning mathematics with understanding. https://doi.org/10.1007/s00280-010$1301-5$

Mills, S. (2016). Conceptual understanding: A concept analysis. Qualitative Report.

OECD. (2013). PISA 2015 Draft Science. In OECD Publishing. https://doi.org/10.1177/0022146512469014 
Reddy, V., Visser, M., Winnaar, L., Arends, F., Juan, A., Prinsloo, C. ., \& Isdale, K. (2016). Timss 2015. In TIMSS 2015: Highlights of Mathematics and Science Achievement of Grade 9 South African Learners. Human Sciences Research Council.

Sanjaya, W. (2010). Strategi Pembelajaran Berorientasi Standar Proses Pendidikan. System.

Sopamena, P. (2017). Karakteristik Proses Berpikir Mahasiswa Dalam Mengonstruksi Bukti Keterbagian. Jurnal Matematika Dan Pembelajaran, 5(2), 169-192.

Tatar, E., \& Zengin, Y. (2016). Conceptual Understanding of Definite Integral with GeoGebra. Computers in the Schools. https://doi.org/10.1080/07380569.2016.1177480

Zahner, W., Velazquez, G., Moschkovich, J., Vahey, P., \& Lara-Meloy, T. (2012). Mathematics teaching practices with technology that support conceptual understanding for Latino/a students. Journal of Mathematical Behavior. https://doi.org/10.1016/j.jmathb.2012.06.002 